\title{
The Dichotomy of Pain and Hope in Bhutanese Nepali Diasporic Poetry
}

Ramji Timalsina, $\mathrm{PhD}^{*}$

\begin{abstract}
Diaspora is a locale where both the pain and hope work together. The pain of being separated from one's homeland is compensated with the hope of a better life than that of home back. The creative writings of the diasporas reflect the same dichotomy of pain and hope. This exploratory study on Bhutanese Nepali diasporic poetry displays the same features: the Bhutanese Nepali diasporans have a life full of pain at the loss of their homeland, but they are living with the hope for good life in the days ahead. On the one hand, the trauma they have undergone because of expulsion from their homeland, the experience of being refugees in Nepal for about two decades, and the hardship of transition caused by the third country settlement has been expressed in their poems. On the other hand, their creations show the rays of hope for their life ahead in the host land. They have hopes for a good life, for the preservation of their culture, and real return to Bhutan. In both the themes and styles, many poems simultaneously display both of these aspects of their lives.
\end{abstract}

Keywords: Bhutanese Nepali Diaspora, dichotomy, homeland, hope, host land, pain.

\section{Possibility of Hope in Diaspora}

Discussions on a diaspora, its life and the creations mostly deal with the difficulties the diasporans have to face in the host land and their sorrow of leaving the homeland. But if the life was full of problems and pain only, would the diasporas grow continuously in the world? It is not the case even because all new diasporas are not the results of forceful expulsions of the people from their homeland. If we take the case of the New Nepali Diaspora itself, it is the result of individual's desire to migrate to the places with better opportunities than that of Nepal. The Nepali Diaspora growing in the western nations these days is its example. So, is it academically justifiable to study only the lope side of diasporic life? Critic and researcher Govinda Raj Bhattarai, in his discussion on transnational Nepali people working in the Arabian land, raises the issue

\footnotetext{
*Dr. Timalsina has earned PhD in Enlglish from Nepal Sanskrit University and published five books and dozens of articles in the related field. He has also participated in several national and international seminars. Currently he is working as Lecturer in English at Mahendra Multiple Campus, Dharan, Tribhuvan University, Nepal.
} 
and argues that it is time to see the other good side of such migrations (19). This is necessary even in the study of diasporic societies.

This article tries to study both of these aspects of the life of the Bhutanese Diaspora presented in their poetic creations.It tries to show that if even the people of this diaspora that is created with great troubles and tribulations have the dichotomy of pain and hope, the other diasporas made up of gradual accumulation of the members surely have both sides. And the studies on diaspora need to take this reality into serious consideration. This article explores into the themes and styles of sixteen representative poems composed by the Bhuanese Nepali diasporans; and comes to a conclusion about their life in the diaspora.

\section{Images of Pain and Hope Intermingled}

Many poems present beautiful images that intermingle pain and hope; and they show the complete life of the Bhutanese Nepali Diaspora. This section deals with some representative poems of this style and theme. The first among them is ShivalalDahal's poem entitled "AniTyaheebaataNayaaShristiHunchha" ["There Starts a New Creation"] published in 2010. It was the early phase of third country resettlement of the Bhutanese refugees living in eastern Nepal. After two decade long suffering as refugees, they were going to get their own home in a host land. They, mainly the young generation, were excited for this achievement that was gained at the cost of leaving the dream of returning Bhutan forever. The total destruction of their past, of their history in Bhutan, was just a matter of memory at that moment of resettlement. Many aged people were unhappy at this because their dream was to return to Bhutan where their youthful vigour was used in the making of the society, the identity and the nation. The refugee community was split into two factions: those happy youths for getting the chance of resettlement and starting a new life there; and their unhappy guardians. Dahal's poem addresses this reality. It is a short composition in six lines:

Flowers bloom

And drop

And from the same point

Starts a new creation

This is how here

The eternal course of life goes on. (11. 1-6)

Here, the images of blooming and dropping of flower symbolize the life and death, hope and pain together. Life is hope; and death is pain. But one death does not end the continuity of humanity. As birth, bloom (life) and death make continuous process of existence, so is the continuity of one society. Referring to Bhutanese Nepali society, the poet takes their expulsion from Bhutan as a dropping of a fully bloomed 
flower. But it was not the end of the future of this society. They were about to set up a new society in the host land that they were going to resettle. They would bloom there; and would forget or at least compensate their pain that they have undergone. Thus, life is made up of the dichotomy of pain and hope; and so is the theme of this poem.

The same theme is directly expressed by Suraj K. Budhathoki's poem "Uprooted!" It starts with the pain the Bhutanese Nepalis underwent: "Expelled by the thousands /Lost, starved, and dream squashed" (1l. 1-2). The same stanza has the third line: "Found a land, cheered and welcomed." The dichotomy of pain and hope/achievement continues into the second stanza:

Uninvited, rejected and found yet another

Land in distant ocean,

Salty, harsh and fresh free-doom scanty I taste

But I rise in my hearts to 'live or die' and rest. (11. 4-7)

Pain and hope are intermingled in most of these lines. Line four starts from the pain of being "uninvited and rejected"; but it ends at their finding of another land. The land is there, but not so near to their homeland and symbolically the culture they are accustomed with: "Land in distant ocean". The next line in the first half presents the salty and harsh life, but the second half deals with the fresh beginning of life. It is thought to be full of freedom as the west, especially the USA, is the land of dream. But for the people newly arrived from a different socio-political and cultural background, the freedom sometimes turns to be the source of doom. The poet indicates this reality with the breaking of the word 'freedom' into 'free' and 'doom': The freedom can be the reason for the doom of their culture and so may be the doom of their life itself. But they are doomed to accept it as there is no better option than this one. As a result, they are committed to rise at least in their spirit ("heart") though not in terms of daily material existence. At least, they have freedom to live or die on their own. The poem ends with the dichotomy of loss and gain:

Roof lost, and roof found

Life lost, and life found

Smile, sadness, love and lifelessness

If life I learn, take it light and smile. (11. 8-11)

Starting their life at all kinds of loss and pain, now they are happy to get at least the basic requirements of life; and so they are hopeful for their future.

The difficulty of adjusting in a new land is presented by J. N. Dahal's poem "Banda Dhokaa" ["Closed Door"]. This dramatic cum narrative poem presents two characters: one the narrator and the other one is a confused actor who represents confused Bhutanese Nepali people who do not see any good at settling in the West. The 
poem starts with the sadness and shock of the second character at a full moon midnight. He is standing at the eaves of his house looking at the moon and says: "The door to the east is closed forever/Probably it will never open" (11. 4-5). These lines indicate the closure of the door to enter into Bhutan where they spent most parts of their lives. Now, the land he is standing on is that of Nepal from where Bhutan lies to the east. It also relates to the eastern culture the Bhutanese Nepalis are accustomed with. Now (in 2018 when the poem was composed), in the diaspora i.e. the west, it is not possible to follow and observe the same cultural tradition they had observed in Bhutan and Nepal. Realising his shock, the narrator shows him the next door opened at the west. There is the possibility of starting a new life adapting new culture and life style. But that character does not see it and so does not believe what the narrator reports.

The character continuously talks about the closed door. It is the expression of the shock at the loss of culture and long earned identity. The loss is so intense that his eyes cannot see any new door; his mind cannot realize the other possibilities. The narrator senses that the situation is getting worse: The character may suffer more than this. So, he snatches away the glasses the character has been wearing; and signals to the open sky. Now, the character wonders at the new sight that he never imagined existing. He clears his dazzled eyes; and finally accepts that there really exists a door in the west, too. And the door is open! Then he regrets on seeing only the closed door in the east for so long a time of his life. He ultimately realizes that it is good to enter into the space of new and multiple possibilities through that open door. Here, the door is a powerful image cum symbol: Looking at the lost past one can only be painful and sad. It is necessary to accept the new realities and future possibilities to live a life with hope. Two poems by SanchamanKhaling express the similar dichotomy of pain and hope with the use of images such as night versus light, blooming flowers versus dropped flowers, evening versus morning, and moon and stars at a distance versus moons and stars in his own mind. One of these two poems is "EkGuchchhaaPhoolakoBihaanee" ["The Morning of One Bouquet Flower"] published in 2009. The persona in the poem reports his thoughts in the night and in the next morning. Every night he falls asleep with wishes that the world would get light and he would be able to offer a bouquet of night jasmine [parijat] to his beloved the next morning. But when he gets up, he always finds that all the flowers have dropped and faded. This has become his life-long experience. The pain of a lover (of life) in such a situation is beyond explanation. But still his hope of getting enough flowers to make a bouquet has not faded away from his life. Despite the pain and suffering, hope continues. It is how one's life continues.

Khaling's next poem "E DoorakaaChaandanee!” ["Hey, Moon at a Distance!'] published in 2009 presents how the persona lives the life of a dream chaser. Though the moon (i. e. the object of dream or a happy and fulfilled life) is at a great distance, he is 
ready to follow it as long as his life continues to exist. When he reached near it, the moon suddenly hid itself inside the cloud. Some other times, it was the no moon day: He was always baffled. On this background, he challenges the moon that he will live alone. No matter how hungry he has to live in his life, he has learnt to celebrate the lonely life in darkness. This indicates the fate of Bhutanese Nepalis to live a life full of pain. They have learnt to celebrate the same. Though they cannot materialize their dream, they have preserved them in their imagination. The poem ends at the same note:

But these days

I have planted innumerable moons

I have sowed the stars

In the barren land within me

That's enough! (11.11-15)

These are a few,out of many,examples of the poems made up of the use of images of pain and hope intermingled.

\section{Diaspora as a Space of Dream}

At the beginning of the process of resettlement, the Bhutanese Nepali youths were hopeful. Their pain of being refugee was about to end; and a new life in a new space was about to begin. At least, they could search for a job as they wished to have; they would have a home the government of the host land prepared for them; their children would get free education in an advanced nation; and their aged family members would get free medical treatment. All these were their dreams for the decades; and they would be materialized soon. Poets gave expression to these hopes of the community and treated diaspora as a land of hope, happiness and prosperity.

YugDawadi and SanchamanKhaling have composed poems in this theme. Dawadi's poem "Anubhuti" ["Realization"] published in 2009 shows the value of diaspora in contrast with the refugee-life the Bhutanese Nepalis underwent. The poem begins with the search for the rays of light in pitch darkness of the no moon day. Carrying the heavy heart at the loss of kiths and kins, they continuously seek fora formula of better possibilities in life. The children born as the babies of the refugees, their mothers full of tortures of life and their helpless fathers have now got the New Land i.e. the America, the land of dreams! The poet believes that it is the beginning of the Spring Season. The people have realized the value of happy land devoid of heathaze in their horizon. It is a fresh morning that can help germinate new dreams in their life. Their happiness, enthusiasm and desires have started to walk together. As a result, they have started imagining better life; have hoped for the recovery of the painful wound; and finally their mind has become stable. The poet realizes the beauty of these 
achievements and finds the beginning of a new love of life. They have begun to feel that their life is meaningful to live on.

The new atmosphere has given them the mood of celebration. Khaling's poem "Happy Holi" (2009) portrays the same picture of celebration. He finds the scene full of rainbow colours that are ready to decorate their happiness and fortunes in life. Though many things are left to be fulfilled in their life, these colours can cover them and create the mood of celebration. Slowly, the wounds of the widow's barren brows, orphan's hunger and thirst, and that of the broken homes of the homeless people will be recovered when they get both home and hope in the new land. The poet implores the community to start filling these gaps with colours (hopes) of life so that the rest of the pains will be recovered soon.

Poets Devi Pokhrel and R. N. Pokharel celebrate the value of this new achievement with the backdrop of pain the community has undergone for long. Devi Pokhrel's poem "Motherhood Reverted" published in 2010 treats the new land as a new mother: "a queer woman with her open heart/Reverted him his lost motherhood" (11. 3536). These are the last two lines of the poem. The poem portrays the picture of the bad and forsaken life of a baby, symbolically the Bhutanese Nepalis. Their real mother who gave this baby's birth is Bhutan that finally "ordered her fraudulent kith and kins to/Throw him in the waters" (11. 15-16). When that did not work well, in the order of the same mother i.e. Bhutan as a nation, the so called motherland managed to take him away at a midnight to "so far, so distant to/Put him in an isolation and evanescence" (11. 19-20). She did not care when he "screamed, cried and asked for help" (1. 23). He had to bear uncountable types of troubles and tribulations. But "with the sanguinity of getting/Tower of strength he moved forward" (11. 27-28). He continued his journey of life and finally reached to the lap of this queer woman i.e. the USA that welcomed him with an open heart. Now he/they feel the love of the motherland. America is their nation now. They are living and working with hope there.

R. N. Pokharel, in his poem entitled "Defeating Double Bind" published in 2009, also relates the history of the pain and the ultimate achievement of hope and happiness. The narration starts from the hut in one of the refugee camps in Nepal. It was a strange place that "[f]ailed to befriend him" (1. 2), yet he tried to smile. He has the experience of: "His Earth-limited to standing his hut/Witnessing his interminable misery/Witnessed his parents' demise" (11. 11-13) and many other troublesome times. He learnt to appreciate his own "interior might" and when he could not do it, he also could not try to take the help of wine "to kill his inner fire" (1. 18):

His mind duly denied.

His hands often touched suicide rope

Eyes located apt sites for valediction; 
His mind earnestly denied. (11. 19-22)

He endured all these troubles and continued to live. As a result, he could reach to the land full of opportunities for a new beginning: "Naked flora of late winter/Casually anticipating Spring" (11. 28-29). Thus, those who could bear all the troubles of expulsion from the birthplace, and life of refugees could finally achieve their life as they expected to live in the USA, the diaspora. This is a land of hope, and of dream and the land of life for them.

\section{Hope of Cultural Preservation and Return to Bhutan}

Once the Bhutanese Nepalis got settled in the third country and were able to be free from the life of refugees, they had to undergo new types of troubles. The Nepali culture that they could perform and observe both at their homes in Bhutan and in the refugee camps in Nepal was not easy to preserve and observe in the host land. Once the door to the east was closed, they had to make themselves ready to adjust with the door at the west. The culture that they carry in their blood and the culture that is outside in their newly acquainted society did not match. Instead, there was a conflict between these two. It was a new cause for their shock in life. And then they began to cherish a new hope: hope to preserve their culture in the diaspora as long as possible.

Poet Dona Acharya has given expression to this difficulty in the diaspora. Acharya's poem "Bhaanu-Smriti" ["Reminiscing Bhanu"] is an example. 'Bhanu', here, refers to Nepali poet BhanubhaktaAcharya. 'Bhanu' is a cultural symbol for the Nepali speaking people across the globe. He is believed to haveemotionally bound Nepali society two centuries ago through his poetry. His Ramayana is such a beautiful Nepali epic and a carrier of cultural teaching to the then Nepali society. So, Bhanu is taken to be the founder of Nepali language, emotion, culture and life.

Acharya's poem "Reminiscing Bhanu" expresses both the problems and commitment to preserve Nepali language and culture in the diaspora. The poem starts with the idea of the continuity of the language and culture in the host land:

I have come here

Carrying the Bhanu

He may have set there

He has risen here

In the next hemisphere

With new rays. (11. 1-6)

These lines show how culture travels with its followers. Many people are inconsiderate about their culture even in Nepal these days; but those who have reached to the next hemisphere have understood its value for existence. They cannot forget the 
love of Bhanu because his love was"spoken/With my childish tongue/With my birth" (11. 9-11). To love one's community in the diaspora means to love the language and culture.

In this context, the Bhutanese Nepali community has to face some serious questions regarding their culture and identity: Can the strangeness (stranger's culture) overtake the Nepali culture? Would the independent Nepali community go on embracing our glory? The persona, after asking these questions, reports that while he was facing these questions, he happened to encounter Bhanu in his dream. Then the poet feels secure that their language, their community and their glory would not vanish. Bhanu's dream of emotional and cultural unity among the Nepali people will be shining like the sun. Thus, this poem addresses the cultural crisis of the Bhutanese Nepalis in the diaspora along with their hope of and commitment to the preservation and continuity of their language, culture and consequent identity.

Connected with their preservation of culture is the idea of their return to Bhutan where they learnt it. If returning Bhutan physically is not possible for the community as a whole, it is possible for the diasporans to return to their cultural heritage that they develop in the host land. It means they can preserve and promote their language, dress, food, festivals and other culture related ideas and practices; and with them they can feel at home. It is the only possible homecoming of the diasporans. R. N. Pokharel's poem "I'm Still Alive" gives expression to such a wish of Bhutanese Nepali Diaspora. He has connected this wish with the loss of their culture because of the forceful eviction from their homes. The persona in the poem narrates the incidents/accidents of the day when he was fifteen and they were leaving their home forever.

His parents bagged everything possible before they left home. At the moment of departure:

My pa looked towards his hard earned land,

Hard earned orange trees his hand hath planted.

My ma cautiously with a wish

left the door open and wept

And we set steps. .. to unknown destination. (11. 10-14)

The rulers of Bhutan wanted them "to finish and rot/Decay and never return" (11. 25-26). But they survived in the refugee camps for twenty years. Again, when he was thirty five, they once more bagged everything they could for a new flight. But this time, they were not so sad like in the first time because they were flying to the USA with a hope of new life with comfort and safety. Now, they live in the USA, but they have not lost their hope to return to the home they have left open:

My ma who left the door open -

Is still alive. 
My pa who looked toward his hard earned land

Is still alive.

My the then childish eyes

- Matured. Has witnessed visualized. (11. 52-57)

When he remembers all these events, incidents/accidents and evaluates his present, he finds within him:

Patriotism blooming

Has hope magnified,

Heart grown stronger,

Amity flourished,

Wit enriched. (11. 58-62)

With all these feelings, his hope of return to the home and homeland gets stronger:

Bliss from 'The bag'

Shall be mine one day,

Thro' The door I shall enter and rise,

The evasive ploy be mirrored.

I'm still alive. (11. 63-67)

Till life persists, hope continues. Pains are to be borne and pushed back to past, to history, to memory. What one needs to cherish is hope, hope, and only hope. The Bhutanese Nepali diasporic poems express the same theme of life in total.

\section{Commitment within Despair}

The poems also express the Bhutanese Nepali Diaspora's hopeful commitment within despair. Yati Raj Ajnabee, KhagendraGautam, L. B. RikhamMagar, DharmendraTimsina 'Kshitij' and Rup Narayan Pokharel's poems are some representative creations in this regard. Ajnabee's "Fear Fears with Fearlessness" presents his and his generation's commitment to fight against all types of obstacles in their life. Its main focus is on fighting against the tyrannical Bhutanese monarch and regaining what they have lost because of his injustice inflicted upon them.

The poem begins with the torture the parents' generation underwent:

Shackled was your father

With tyrannous chain.

Tearful was your mother

With angst and sharp pain.

With thine eyes closed

You did keep on seeing. (11. 1-6) 
And the poem presents how blindfold, deaf and heartless the Bhutanese Nepali youths are compelled to be. The whole new generation is dumbfounded because of fear. But the poet wants them to end such a condition and be aware of their duties, responsibilities and capabilities: "Wake, wake up! You have/Slept many nights so dead" (11. 17-18). He implores them to study and understand the history of the world, their own history and be ignited for the necessary revolution. It is only through a new revolution they can regain their land lost to an autocrat: "Have fulfilled your dream" (1. 28). He encourages them to be committed to the cause and realize that "Fear fears with fearlessness"(1.32). It is not only to regain the land lost, for any kind of achievement in the life full of despair, we need to be fearless. Once we are fearless, even the fear hesitates to grapple us. What we need is the commitment to the cause and fearlessness in action.

KhagendraGautam in his poem entitled "Ma AaunechhuSaathee" ["I'll Come, My Friend"] published in 2014 expresses the commitment that Ajnabee's poem demands. Gautam's persona expresses his commitment:

I'll come, my friend

I'll come with laughter

With red man

In red dress carrying a red flag

Sure, I'll come. (11.1-5)

Then the poem deals with the torture his friends back in Bhutan might have been undergoing. He assures them that nothing can obstruct him to enter into his nation, his area; and so finally he will meet his friends. Every people from the red huts will be with him. He will be as recreative as the Raktabij of Hindu mythology, and also as destructive as the bombs against the enemies of the people. Finally, he declares that he will be victorious and will free every poor man shackled in Bhutan.

Such a commitment is found even in DharmendraTimsina's poem entitled "MaileEutaaKathaaLekhnuChha" ["I Have to Write a Story"] published in 2018. The poem presents the postcolonial argument that all written histories are lies because they have got written by the rulers in such a way that these histories favour them; and they help continue their domination over the ruled ones. The persona denies the need of writing the history of everyday generalities. It is necessary to write the history of pain, torture and even happiness the Bhutanese Nepali community has undergone. It is necessary because these people have started feeling shy of talking of their past and being fearful to tell their real stories. The life they really lived back in refugee camps in Nepal must come out. The new car, a tall modern building and the vacant idealism do not represent who they are. What really represents their life is what they did, underwent 
and felt in the past. It is to preserve their identity, their culture and ultimately their life. The poet thinks that it is the necessary commitment of the whole community. The poem entitled "MrityukoMaidaan" ["Ground of Death"] composed by L. B. RikhamMagar and published in 2015 recounts the troubles people have to bear anywhere in the world. His indication is towards the problems the Bhutanese Nepali community has to undergo even in the diaspora despite their initial excitement in the third country resettlement. The poet has found the life in the host land, too, full of difficulties; but he does not see any alternatives for them to follow. So, he implores the whole community to be committed to live and enjoy it in any way possible to do. The poem starts from the lines:

With the upward flow of smoke

A pack of future

And a little hope for life

Is padlocked in a box. (11. 1-4)

It is not only the condition of the Bhutanese Nepali diasporans, but also that of any people in the world. Many people's hope for life and the dreams for the future are covered within the damaged walls. People are seen praying the God for their safety. The poem moves ahead with the portrayal of such a picture; and towards the middle the poem gives a terrible picture of the present day world:

May be - human life is a slaughter house

Everywhere there are sprays of blood

In the road, town-square and lanes

On the walls of all types

There is the holi of blood. (11. 19-23)

The more bizarre scene of the present inhuman world is presented ahead. Symbolically, it is the life of the Bhutanese Nepali Diaspora. They did not get painless life wherever they reached. So, the only solution is to be committed to the community and help each other for the preparation of good future ahead. So, the poem ends at the lines:

Let us all gather together

Let's celebrate the life

Let's live

And let others live, too. (11. 49-52)

These lines highlight the fact that they need to work together and help each other to live a sustainable life in the diaspora despite the fact that life is full of difficulties. This reality is further highlighted by Rup Narayan Pokharel's poem entitled "For the Unborn" published in 2009. The poem is an emotional piece conveyed in a narrative 
form. Early in the dawn of late autumn, a letter is dropped into the room of a semiurban house. The postman is unknown. A young lady picks up the letter. This is a letter of love and advice of a dying husband to his pregnant wife,Seela. He is going to be a martyr for the community and its freedom and identity. The letter relates that it is sure that the government people will bring to her his "stiffened corpse". He requests her to "have a snap" of his face because he does not have any of his photos to show the would be child: "Do it just for the sake/Of our progeny/To at least imagine my being" (11. 3739). More than this, his request is to take care of the newcomer i.e. their baby: "Take care of the fetus/Forthere flows my blood/And your only living hopes" (11. 32-34). Then he suggests her to give the unborn, after its birth, a name they have chosen together.

This is a very symbolic poem. The dying father is a history now. He has used his life for the nation, for the community and for making the society good one for his next generation. But all his dreams came to an end when he was mortally wounded and was sure to be a martyr. This is a bloody history of the nation/community for the new generation of Bhutanese Nepalis. Now, at the demise of the father, mother is lonely and helpless; but she has a great responsibility of giving birth to a baby that is already in her womb. The mother is a present day reality and the baby is the 'hope' for future. Both the history and the present have their roles in the making of the future. Both of them are full of pain, suffering and difficulties. But these all negativities are borne for making the future good.

Symbolically, this poem reads the total history of Bhutanese Nepalis. Though their past and present are full of pains and sufferings, they are hopeful for the future. It was 2009 when the poem was published; and it was the time the third country resettlement process was going high and mighty. The Bhutanese Nepalis, mostly the young generation, took it as an opportunity to settle and create a new diaspora that could give them a hopeful future. The symbol of the unborn 'baby' is used to refer to the same future society and their life in it. This is a picture of the diaspora the migrants make before they reach there; before it is really created.

Bhutanese Nepali society was one section of the Nepali Diaspora. As they were expelled out of Bhutan, they came back to Nepal as refugees. This situation shows that for the diasporans, their homeland is just a land of faith and emotion, not the land that can support them in material terms. Once a diaspora, they are always a diaspora. So, they need to search for their happiness in the diaspora itself. If one place cannot provide them what they need, they dream of the next; and so they search for their new hopes and their fulfillment so that they can forget the pain they have undergone in the history and at present. As the poems analyzed above show, diaspora is always a society of hopes forfuturedespite the past and present sufferings. 


\section{Conclusion}

Bhutanese Nepali diasporic poetry presents the dichotomy of pain and hope of the community. The past of torture and the present full of difficulties are used as the background for the future with hope in their life. The same is given expression through the poems analyzed in this study. Not only the themes,but also the styles of the selected poems represent the order of pain to hope that the community has experienced. Most of these poems start from the presentation of the pain that the community underwent in the past and/or the difficulties they have to face at present; and they end at the hope of the possibility of a good future. Some poems alternatively present pain and hope from the beginning. Even in them, pain precedes hope, sometimes in each such line: the first half is about the pain and the second half is on hope. So, these poems show that the life of the poets and their community gets reflected in their creative writings. At the same time, the poems composed in 2009-2010 have this dichotomy more in ratio than in the poems written before and after that period. It is because the third country resettlement process had given the youths of the Bhutanese Nepali community a great hope to overcome their painful past. Finally, this study shows that the dichotomy of pain and hope is the major aspect of a diasporic society; and so studies on diasporic life and literature need to pay further attention to this reality.

\section{References}

Ajnabee, Yati Raj. "Fear Fears with Fearlessness.” Sep. 2009. http://bhutaneseliterature.com

Acharya, Dona. "Bhaanu-Smriti." ["Reminiscing Bhanu."] July 2009. http://bhutaneseliterature.com

Bhattarai, Govinda Raj."SampoornaAsthaayee, ShramikDaayaasporaakoSaahityachitraSaayadYastaiHunchha." ["Probably This is the Picture of Literature from All Temporary Labour Diaspora."] Registaan Ra Sapanaa: SaahityikSangaalo[Registan and Dreams: Literary Collection], edited byTirhaSangamRai, DipakBhewal and HemantParadeshi. INLS and NavoditLiterary Mobile Library, 2068BS/2012, pp. 8-20.

Budhathoki, Suraj K. "Uprooted.” April 2017.http://bhutaneseliterature.com

Dahal, J. N. "Banda Dhokaa."["Closed Door."] Dec 2018.http://bhutaneseliterature.com

Dahal, Shivalal."AniTyaheebaataNayaaSristiHunchha." [“And There Starts a New Creation.”] July 2010. http://bhutaneseliterature.com

Dawadi, Yug. "Anubhuti." ["Realization.”] May 2009. http://bhutaneseliterature.com 
Gautam, Khagendra. "Ma AaunechhuSaathee." ["I'll Come, My Friend."] May 2014.http://bhutaneseliterature.com

Khaling, Sanchaman. "EkGuchchhaaPhoolako Bihaanee." ["The Morning of One Bouquet Flower."] July 2009. http://bhutaneseliterature.com

---. "E DoorakaaChaandanee.”["Hey, the Moon at a Distance."] Dec 2009. http://bhutaneseliterature.cosm

---. "HyaappeeHolee." ["Happy Holi."] May 2009. http://bhutaneseliterature.com

Magar, L. B. Rikham. "MrityukoMaidaan.” [“Ground of Death.”] June 2015. http://bhutaneseliterature.com

Pokharel, Rup Narayan. "Defeating Double Bind.” July 2009.http://bhutaneseliterature.com

---. "For the Unborn." June 2009. http://bhutaneseliterature.com

---. "I'm Still Alive ...." August 2009.http://bhutaneseliterature.com

Pokhrel, Devi. "Motherhood Reverted." June 2010. http://bhutaneseliterature.com Timsina, Dharmendra. "MaileEutaaKathaaLekhnuchha." ["I Have to Write a Story."] Dec. 2018. http://bhutaneseliterature.com 